\title{
SOME HETERONEMA SPECIES (EUGLENOPHYTA) OCCURRING IN ŁECZNA-WŁODAWA LAKELAND (EASTERN POLAND)
}

\author{
MAŁgORZATA PONIEWOZIK \\ Catholic University of Lublin, \\ Department of Botany and Hydrobiology \\ C.K. Norwida 4, 20-061 Lublin, Poland \\ e-mail: gonium@kul.lublin.pl
}

(Received: April 28, 2005. Accepted: June 30, 2005)

\begin{abstract}
One new Heteronema cf. distigmoides Christen and three rare taxa of H. acus (Ehrenberg) Stein, H. spirale KLEBS and H. nebulosum (Dujardin) Klebs were reported for the Polish flora. All of them were found in the mesotrophic Lake Piaseczno and in a small village pond in Kaniwola, in 2002. Both water reservoirs are situated on the Łęczna-Włodawa Lakeland (Eastern Poland).

The above mentioned species are new to the flora of the Łęczna-Włodawa Lakeland, probably because of insufficient research, which was carried out on euglenophytes in this area previously. All the presented species are described thoroughly and illustrated in this paper.
\end{abstract}

KEY WORDS: Euglenophyta, Euglenida, Heteronema, taxonomy, phytoplankton.

\section{INRTODUCTION}

Heteronema Dujardin 1841 is one of the colourless genera of Euglenophyta (Euglenida) belonging to the order Heteronematales (Heteronematina) (Leedale 1967; Walne and Kivic 1989). To this order also belong the Peranema, Urceolus, Entosiphon, Dinema and Ploeotia genera. All of them are phagotrophs with special ingestion apparatus, cells are naked, non-rigid to rigid with moderate euglenoid movements. They have 1 or 2 emergent flagella; 1 extends anteriorly, flickering at the tip.

The number of known taxa of the genus Heteronema has been increasing during the last 50 years: 19 species were given by Huber-Pestalozzi (1955), 22 by Starmach (1983), 25 by Lee et al. (2000) and 43 by Schroeckh et al. (2003). Heteronema taxa occurring in fresh and marine waters are common and widespread.

The taxa of the genus Heteronema have been rarely reported from Poland. Only four: H. spirale - Dreżepolski (1925), H. nebulosum - Dreżepolski (1948), H. acus - Słabęcka-Szweykowska (1953), and H. globuliferum - Wołowski (1998) have been found.

Four taxa of colourless euglenophytes which were found in the near-shore zone of Piaseczno Lake and in the village pond in Kaniwola are presented. This study is a part of more comprehensive investigations on euglenophytes in this area. The degree of knowledge of particular algae groups, especially of Euglenophyta, on the Łęczna-Włodawa Lakeland is still scant. There are only three papers in which in- formation about euglenoids is enclosed (Wojciechowski 1971; Lecewicz 1983/1984, 1998). The mentioned papers contain: Euglena acus var. longissima, E. tripteris, E. elastica, Trachelomonas volvocina var. volvocina, $T$. hispida, T. stokesiana f. stokesiana, T. oblonga, T. magdaleniana, T. abrupta var. abrupta, T. pseudofelix, T. manchurica, Phacus tortus, Ph. pleuronectes, Ph. aenigmaticus, Ph. longicauda, Ph. caudatus var. minor, Ph. hispidulus var. glabrus, Ph. stokesii, Lepocinclis acicularis, Strombomonas longa, S. eurystoma, Colacium vesiculosum. There are insignificant drawing or photo records of indicated species. The phycological papers have a floristic character, they only include lists of taxa. There are not any Heteronema species and there are only three colourless euglenophytes (Astasia dangeardii, Dylakosoma symbionticum and Petalomonas sphagnicola) mentioned.

\section{STUDY AREA}

Piaseczno Lake and the village pond are located in the central part of the Łęczna - Włodawa Lakeland (Eastern Poland - Fig. 1). Piaseczno Lake is a deep (39 m), mesotrophic reservoir, which in summer is intensively exploited as a tourist spot. The pond is small and very shallow (about $0.5 \mathrm{~m}$ ). In summer its depth is reduced to $0.1-0.2 \mathrm{~m}$.

The parameters of the water were: in summer: temperature $-27-30^{\circ} \mathrm{C} ; \mathrm{pH}-8.6-9.7$; conductivity $-184-279 \mu \mathrm{S} / \mathrm{cm}$, in autumn: temperature $-14.1-15.1^{\circ} \mathrm{C} ; \mathrm{pH}-6.9-7.5$; con- 


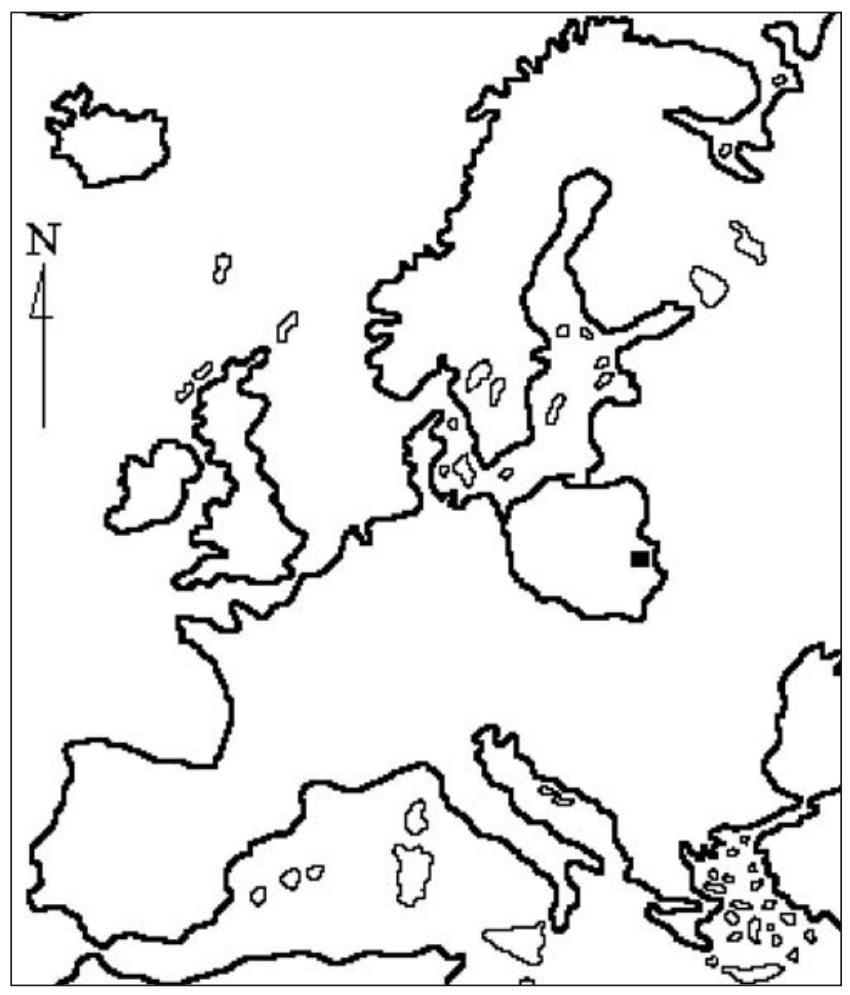

Fig. 1. Location of the study area (Eastern Poland).

ductivity $-161-443 \mu \mathrm{S} / \mathrm{cm}$. In winter the reservoirs within the research area were frozen down to the bottom, so physical and chemical parameters could not be measured.

\section{MATERIAL AND METHODS}

The occurrence of the species in question was noted in August, October and December (under the ice cover) 2002. The material was collected from the near-shore water-bottom layer in $150 \mathrm{ml}$ containers and the samples were kept in a cool place. The observations, drawings, photographs and descriptions were made on the basis of the living material. For immobilization, specimens were treated with $0.5 \%$ solution of either glutaraldehyde or Lugol. Detailed observations of these taxa were carried out using Nikon Eclipse E200 and E600 light microscopes. The photos were taken using Nikon Coolpix 4500.

The data on occurrence of the species both in Poland and other countries were obtained from the Iconotheca of Algae situated in the Department of Phycology, W. Szafer Institute of Botany, Polish Academy of Sciences in Cracow.

\section{RESULTS}

Only four taxa of euglenophytes species rare for Polish flora were found. All of them are described below.

\section{Heteronema acus (Ehrenberg) Stein 1878 (Figs 2, 6)}

Synonyms: Astasia acus Ehrenberg, Heteronema acus f. skuja.

Cells fusiform during swimming, oval in cross-section; 7.4-17.5 $\mu \mathrm{m}$ wide, 56.8-70.0 $\mu \mathrm{m}$ long; slightly narrowing at the anterior end and obliquely truncated, posterior end cle- arly tapering; contractile body movements very rapid, usually cells lengthen and become narrower or shorten and widen, most frequently the cells widen in the central part, so then the cell width is bigger than its length (Fig. 2d), during movements the nucleus and other organelles change their position; after the immobilization the specimens change their shape considerably; pellicle slightly spirally striated, well visible under the highest magnification $(1000 x)$; nucleus slightly shifted to the posterior end or located in the centre of the cell; two unequal, emergent flagella, one of cell length or longer (to 1 1/3 cell length), flickering at the tip, the other thinner and shorter than the cell, up to $2 / 3$ of its length, directed posteriorly; paramylon bodies oval or circular in outline, small and large; ingestion apparatus well developed and visible. Found in summer and autumn samples.

Habitats: canals, puddles, ponds, oxbow lakes, peat bogs, littoral of lakes. $\alpha$ - $\beta$-mesosaprobic (Vetrova 1980).

Distribution: cosmopolitan; recorded in Poland only once by Słabęcka-Szweykowska (1953) in Stołowe Mountains.

\section{Heteronema spirale Klebs 1893 (Figs 3, 7)}

Synonym: Sphenomonas spiralis Playfair var. angusta Playfair.

Cells ovate, the widest in the central part of the cell, 24.7-38.0 $\mu \mathrm{m}$ wide, 19.8-56.8 $\mu \mathrm{m}$ long; 4-5 times spirally twisted; with well visible ribs (Fig. 7a), pellicle fairly thick, smooth and colourless; cells firmly tapering at both ends; euglenoid movements moderate, cell can only contract or elongate during swimming rapidly; flagella two, unequal, located apically; one thicker and 2-3 times the cell length, directed anteriorly during swimming, with a flickering motion of the tip only, the other thinner and shorter than the cell, directed posteriorly. Found in summer samples.

Habitats: puddles, ponds, littoral of lakes.

Distribution: Europe (Ukraine, Lithuania, Russia, Switzerland, Poland), North America, Australia, Asia (Japan). This species has been recorded in former Polish territories (now Ukraine) by Dreżepolski (1925) in Dobrostańskie ponds.

Note: The observed specimens had usually 4-5 ribs (see Klebs description (1893: 373, Tab. XVII, Fig. 12), while in the data from literature they have 5-6 (Huber-Pestalozzi 1955; Popova and Safonova 1976; Kusel-Fetzmann 2002).

\section{Heteronema cf. distigmoides Christen 1962 (Fig. 4)}

Cells cylindrical, round in cross-section, 7.2-14.3 um wide 55.2-57.7 $\mu \mathrm{m}$ long; rounded at the anterior end, narrowed at the posterior end coming to slightly sharpened tail-piece; shape of the cell constant during swimming, can slightly bulge in the middle but come back to its normal shape very rapidly; pellicle very delicately spirally striated or almost smooth; nucleus round and slightly shifted to the posterior end of the cell; flagella two, unequal, one thick of cell length, straight and directed anteriorly during swimming, with a flickering motion of the tip only; the second one thinner and shorter than the cell (about 1/3 of cell length), directed posteriorly; paramylon bodies oval and slightly elongated, usually placed at the anterior part of the cell above nucleus, only few paramylon bodies are below the nucleus; ingestion apparatus poorly developed, not well visible. Occurred singly in the autumn samples.

Habitats: peat-bog ditches, pond mud.

Distribution: Switzerland (Christen 1962). 

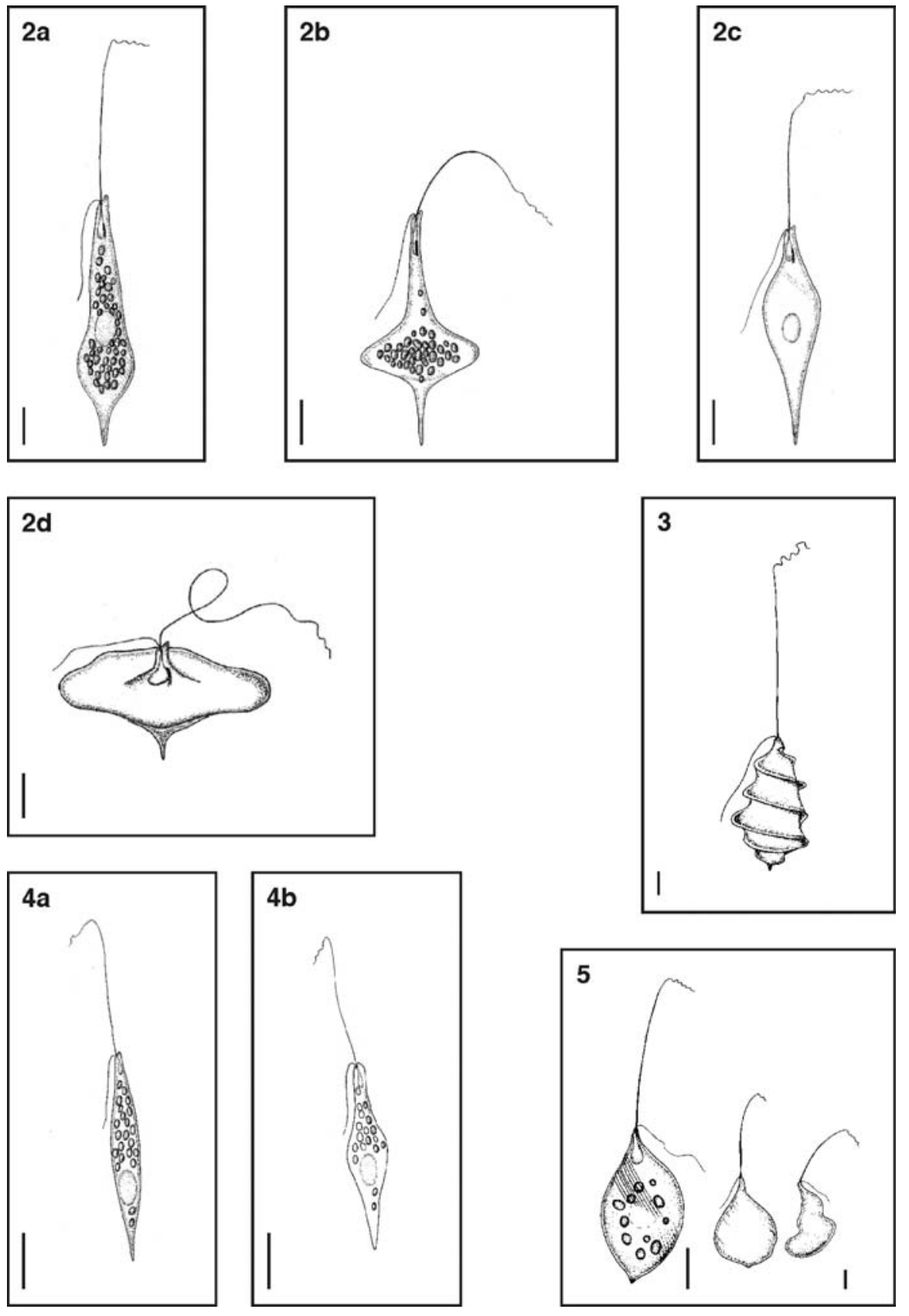

Figs 2-5.

Fig. 2. Heteronema acus, a-d euglenoid movements. Fig. 3. H. spirale. Fig. 4. H. cf. distigmoides. Fig. 5. H. nebulosum.

Scale bars: $10 \mu \mathrm{m}$

Note: The specimens had narrowed posterior end tapering to a slightly sharpened tail-piece, which distinguished them from those described by Christen (1962: p. 183, T. VI, Fig. 7) which had rounded posterior end; the species is similar to Heteronema acus but significantly differ in contractile movements, number of paramylon bodies and size of the cell. It might be a form of Heteronema acus.

\section{Heteronema nebulosum (Dujardin) Klebs 1893 (Figs 5, 8)}

Synonym: Zygoselmis nebulosa Dujardin.

Cells ovoid, pear-shaped, 24.0-25.0 $\mu \mathrm{m}$ wide, 37.1-42.0 $\mu \mathrm{m}$ long; anterior end slightly narrowed and tapered; posterior end broadly rounded or with a short process; euglenoid movements very strong and rapid, cells flexible; the central nucleus can change its position during euglenoid movements; pellicle spirally striated; flagella two, unequal, one thick, 2 times length, anteriorly directed during swimming, with a flickering motion of the tip only, the other posteriorly directed, thin and shorter than the cell; paramylon bodies variable in size, oval. Found in summer and winter samples.

Habitats: puddles, ditches, ponds and fish ponds. $\alpha-\beta$-mesosaprobic (Vetrova 1980).

Distribution: Europe (Sweden, Poland, Hungary, Russia, Ukraine, Latvia) and Asia (China). Recorded in Poland only once by Dreżepolski (1948).

\section{ACKNOWLEDGEMENTS}

The author is grateful to the reviewer for valuable remarks on the manuscript. I also wish to thank Alina Pachońska-Wołowska MSc. for polishing the English version of this work. 

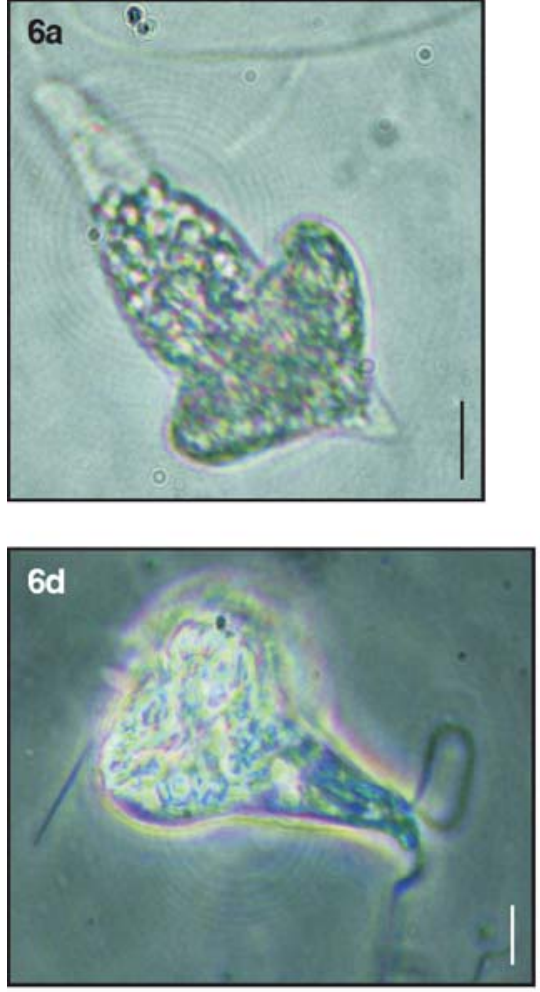
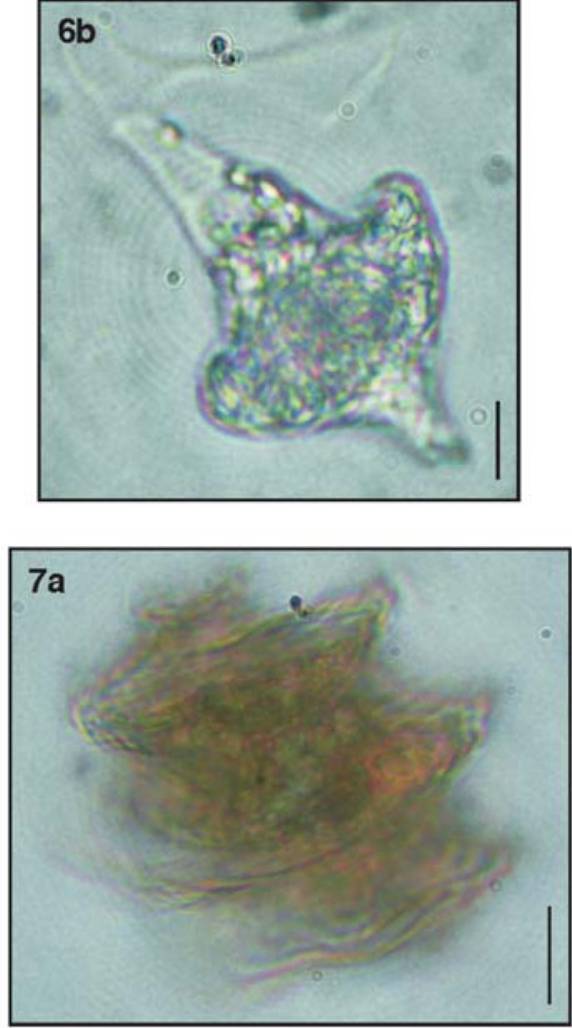
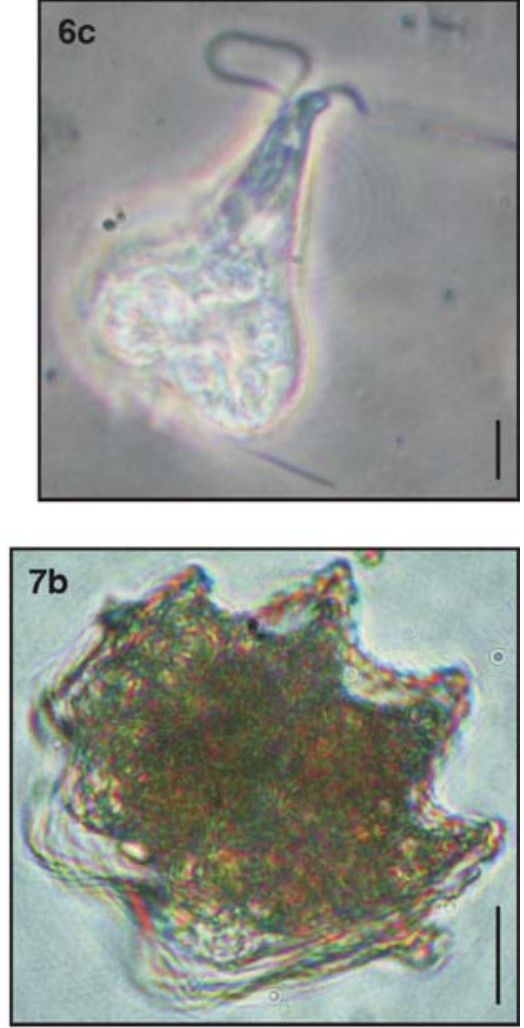
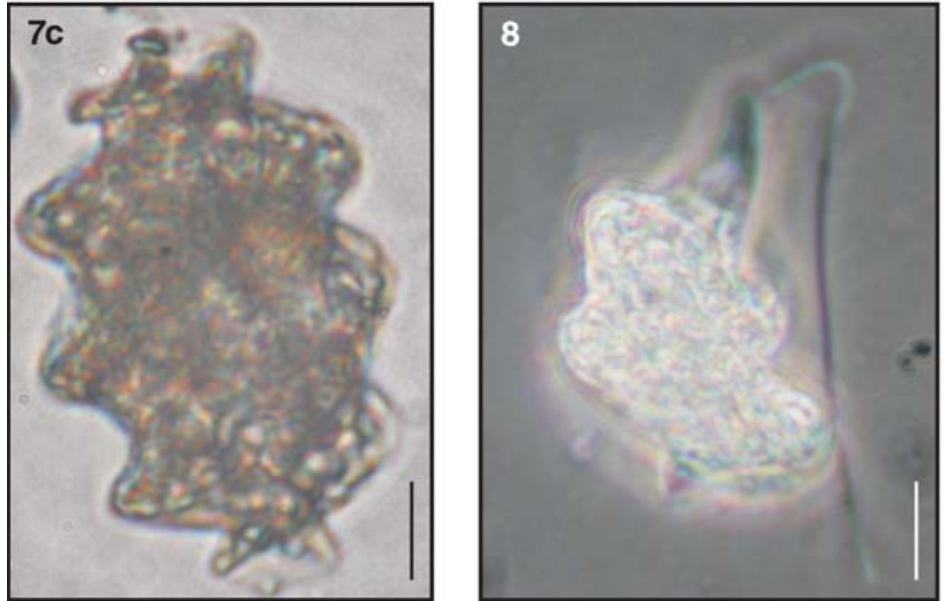

Figs 6-8.

Fig. 6. Heteronema acus. Fig. 7. H. spirale. Fig. 8. H. nebulosum.

Scale bars: $10 \mu \mathrm{m}$

\section{LITERATURE CITED}

CHRISTEN H.R. 1962. Neue und wenig bekannte Eugleninen und Volvocalen. Revue Algologie 6 (3): 162-202.

DREŻEPOLSKI R. 1925. Przyczynek do znajomości polskich euglenin. Supplément a la connaissance des Eugléniens de la Pologne. Kosmos 50, 1: 173-269. (in Polish with French summary)

DREŻEPOLSKI R. 1948. Eugleniny denne - Les eugléniens bentheau. Mat. Fizjogr. Kraju 8: 1-18. (in Polish with French summary)

HUBER-PESTALOZZI G. 1955. Das Phytoplankton des Süsswassers. Band 16, Teil 4: 1-606. Euglenophyceen. Die Binnengewässer. E. Schweizerbart, Stuttgart.

KLEBS G. 1893. Flagellatenstudien. II. Teil. Zeitschrift für Wissenschaftliche. Zoologie 55: 353-445.

KUSEL-FETZMANN E. 2002. Die Euglenophytenflora des Neusiedler Sees (Burgenland, Österreich). Abhandlungen der Zoologisch-Botanischen Gesellschaft in Österreich, Wien. Band 32: $1-115$.
LECEWICZ W. 1983/1984. Characteristics of the dystrophic Lake Brzeziczno on the basis of a two-year investigation of phytoplankton. Acta Hydrobiol. 25/26: 345-357.

LECEWICZ W. 1998. Glony torfowiska Brzeziczno. Annls Univ. Mariae Curie-Skłodowska. C. 53: 167-183. (in Polish with English summary)

LEE J.J., LEEDALE G.F., BRADBURY P. (eds). 2000. An Illustrated Guide to the Protozoa, 2nd Edition, 1400 pp. Society of Protozoologists, Lawrence, Kansas.

LEEDALE, G.F. 1967. Euglenoid flagellates, 242 pp. PrenticeHall, INC., Englewood Cliffs, N. J.

POPOVA T.G., SAFONOVA T.A. 1976. Evglenovye vodorosli (Euglenophyta). Flora sporovych rastenij SSSR 9 (2): 1-278. Izdatel'stvo "Nauka", Leningrad. (in Russian)

SCHROECKH S., LEE W.J., PATTERSEN D.J. 2003. Free-living heterotrophic euglenids from freshwater sites in mainland Australia. Hydrobiologia 493: 131-166.

SŁABĘCKA-SZWEYKOWSKA A. 1953. Wiciowce roślinne zebrane w okolicach Gór Stołowych. Acta Soc. Bot. Pol. 22, 1: 85-92. (in Polish with French summary) 
STARMACH K. 1983. Euglenophyta - Eugleniny. Flora Słodkowodna Polski (Euglenophyta. Freshwater Flora of Poland). 3: 1-594. Państwowe Wydawnictwo Naukowe, Warszawa-Kraków. (in Polish)

STEIN F.R. 1878. Der Organismus der Infusionsthiere III. Naturgeschichte der Flagellaten oder Geisselinfusorien, 154 pp, Leipzig.

VETROVA Z.I. 1980. Bessvetnyje vodorosly Ukrainy ("Colourless euglenophytes from Ukraine”). 182 pp. Izdatel'stwo Naukova Dumka, Kiiv. (in Ukrainian)

WALNE P.L., KIVIC P.A. 1989. Phylum Euglenida, 15: 269287. In: L. Margulis, J.O. Corliss, M. Melkonian. J. Chapman (eds), Handbook of protoctista. Jones and Bartlett Publishers, Boston.

WOJCIECHOWSKI I. 1971. Die Plankton-Flora der Seen in der Umgebung von Sosnowica (Ostpolen) (Flora planktonowa jezior okolic Sosnowicy (Polska wschodnia)). Annls Univ. Mariae Curie-Skłodowska, C. 20: 233-263.

WOŁOWSKI K. 1998. Taxonomic and environmental studies on Euglenophytes of the Kraków-Częstochowa Upland (Southern Poland). Fragm. Flor. Geobot., Suppl. 6: 1-192. 